\title{
Analysis of Forest Landscape Restoration Based on Landscape Connectivity: A Case Study in the Yi River Basin, China, during 2015-2020
}

\author{
Ziqi Bian ${ }^{1,2}$, Lyuyi Liu ${ }^{3}\left(\mathbb{D}\right.$ and Shengyan Ding ${ }^{1,2, *}$ \\ 1 College of Geography and Environmental Science, Henan University, Kaifeng 475004, China; \\ zqbian@henu.edu.cn \\ 2 Key Laboratory of Geospatial Technology for the Middle and Lower Yellow River Regions, Henan University, \\ Ministry of Education, Kaifeng 475004, China \\ 3 Henan Provincial Academy of Eco-Environmental Sciences, Zhengzhou 450003, China; luyi_liu524@163.com \\ * Correspondence: syding@henu.edu.cn
}

check for

updates

Citation: Bian, Z.; Liu, L.; Ding, S. Analysis of Forest Landscape

Restoration Based on Landscape

Connectivity: A Case Study in the Yi

River Basin, China, during 2015-2020.

Land 2021, 10, 904. https://doi.org/

10.3390/land10090904

Academic Editors: Diane L. Haase,

Jeremiah R. Pinto and

Owen T. Burney

Received: 14 July 2021

Accepted: 17 August 2021

Published: 27 August 2021

Publisher's Note: MDPI stays neutral with regard to jurisdictional claims in published maps and institutional affiliations.

Copyright: (c) 2021 by the authors. Licensee MDPI, Basel, Switzerland. This article is an open access article distributed under the terms and conditions of the Creative Commons Attribution (CC BY) license (https:// creativecommons.org/licenses/by/ $4.0 /)$.

\begin{abstract}
Landscape connectivity has widely been recognized as one of the key objectives in studies of forest landscape management, ecological conservation and construction. Protecting virgin forests and afforesting marginal cropland are two long-term ecological projects in China. However, along with rapid urbanization and industrialization in China, the relationship between landscape connectivity and forest landscape restoration (FLR) has not been fully explored. The emergent question concerns whether the connectivity of a restored forest landscape could benefit the local flora and fauna. We evaluated the status of FLR in the Yi River watershed based on remote sensing images during 2015-2020. The forest landscape connectivity (FLC) was investigated using landscape connectivity indicators, applying the theory of landscape connectivity. We also examined the variations of FLC under different landform types (hills and low mountains) according to distance threshold values ranging from $100 \mathrm{~m}$ to $20,000 \mathrm{~m}$. The most appropriate distance thresholds for analyzing FLC in hills and low mountains are $500 \mathrm{~m}$ and $100 \mathrm{~m}$, respectively. The results showed that in this period, the FLC in low mountains was increased, whereas that of hills was decreased. The contributions for reforested patches on the improvement of the FLC were evaluated. In hills, patches that made "very high" and "high" contributions to improve the FLC occupied 15.6\% of the total reforested area, whereas the proportion in low mountains was $25.5 \%$. The results indicated that although rainfed cropland patches have been converted to forest patches, some of them have made small contributions to the FLC. Through this case study, we hope to have confirmed that landscape connectivity analysis could be used as a criterion for selecting important patches in the planning of FLR. Moreover, we have introduced this implementable method for future ecological restoration management programs.
\end{abstract}

Keywords: forest landscape restoration; landscape connectivity; distance threshold; Yi River basin

\section{Introduction}

Landscape connectivity is a parameter to determine continuity among units of landscape spatial structure [1,2]. The definition of landscape connectivity was first introduced into landscape ecology in 1984, and has become one of the core subjects in this area $[1,3]$. It can describe the functions and ecological processes in landscapes and helps to identify organic connections among homogeneous and heterogeneous patches. These organic connections can not only be species' communication among organisms' communities, but also the direct exchange and transference of material and energy among landscape elements [2]. Research on landscape connectivity did not start until 1996 in China, which was relatively late [4,5]. However, with the process of large-scale urbanization and the loss of natural habitats in China, landscape connectivity has received increased attention in recent years. Research on landscape connectivity has been widely applied in fields such as 
the construction of landscape security patterns [6] and urban ecological networks [7,8], assessments of urban land suitability [9,10] and suitable habitats for wildlife [11], land use changes and its effects on landscape connectivity [12-14], etc. Previous studies have shown that landscape connectivity has significant impacts on forest ecosystem functions, such as seed migration and dispersal, animal migration, gene flow, infiltration interference and soil erosion, and further influences the completeness, sustainability and stability of forest ecosystems [14-17].

Forest landscape restoration (FLR) is widely known as an efficient approach to restore ecological functionality, benefit biodiversity, and improve ecosystem services in degraded forest landscapes [18-20]. Prospective forest restoration aims to meet the current and future human needs of forest resources. In China, the Returning Farmland to Forest Program (RFFP) is part of an FLR scheme. This grand ecological program has the largest investment, is the most policy-oriented, has the broadest coverage, and has the highest level of public participation [14]. Henan province initiated the RFFP in 2000, and this program was fully operational in 2002. The RFFP is an ongoing scheme. With the increase in urbanization, FLR will be developed further. The years 2015 and 2020 were the last in the 12th and 13th Five-Year Plans in China, respectively. The selection of this research period was to assess the implementation of the two plans, such as the status of FLR and the variation of forest landscape connectivity (FLC). However, whether the restored forest landscape is more conducive to promote the survival and development of local organisms, and how to assess the importance of cropland patches that need to be reforested before FLR, are questions which remain unclear [14,21-23].

Here, we raised three research questions: How did FLR change between 2015 and 2020? How did FLC change under different landforms? How have the reforested patches contributed to the FLC? In this study, FLR statuses in the Yi River basin in 2015 and 2020 were compared according to the land cover in these two years. On the basis of landscape connectivity theory, landscape connectivity indices that included the number of components (NC) and the integral index of connectivity (IIC) were used to analyze FLC. The index dIIC shows the importance of IIC. During the study period, some rainfed cropland patches were turned into forest patches. We calculated the dIIC of these reforested patches to reveal their contributions to improving the landscape connectivity. This study can help to determine the selection of important patches at the beginning of FLR, hence providing a scientific foundation for regional ecological restoration.

\section{Materials and Methods}

\subsection{Site Description}

The Yi-Luo River is an important tributary on the south bank of the lower reaches of the Yellow River. This typical twin river consists of the Yi River and the Luo River. The Yi River mainly flows through the city of Luoyang in Henan Province, China. The total length of the main stream is $237.4 \mathrm{~km}$. Based on the digital elevation model (DEM) data (overall accuracy of around $30 \mathrm{~m}$ ) of the Central Plains Economic Zone (CPEZ) of China, the extent of the Yi River basin $\left(111^{\circ} 19^{\prime} \sim 112^{\circ} 55^{\prime} \mathrm{E}, 33^{\circ} 39^{\prime} \sim 34^{\circ} 41^{\prime} \mathrm{N}\right)$ was generated by the soil and water assessment tool (SWAT) in ArcMap 10.3 (Esri Inc., Redlands, CA, USA) (Figure 1). The total area of the basin is $5936.71 \mathrm{~km}^{2}$. 


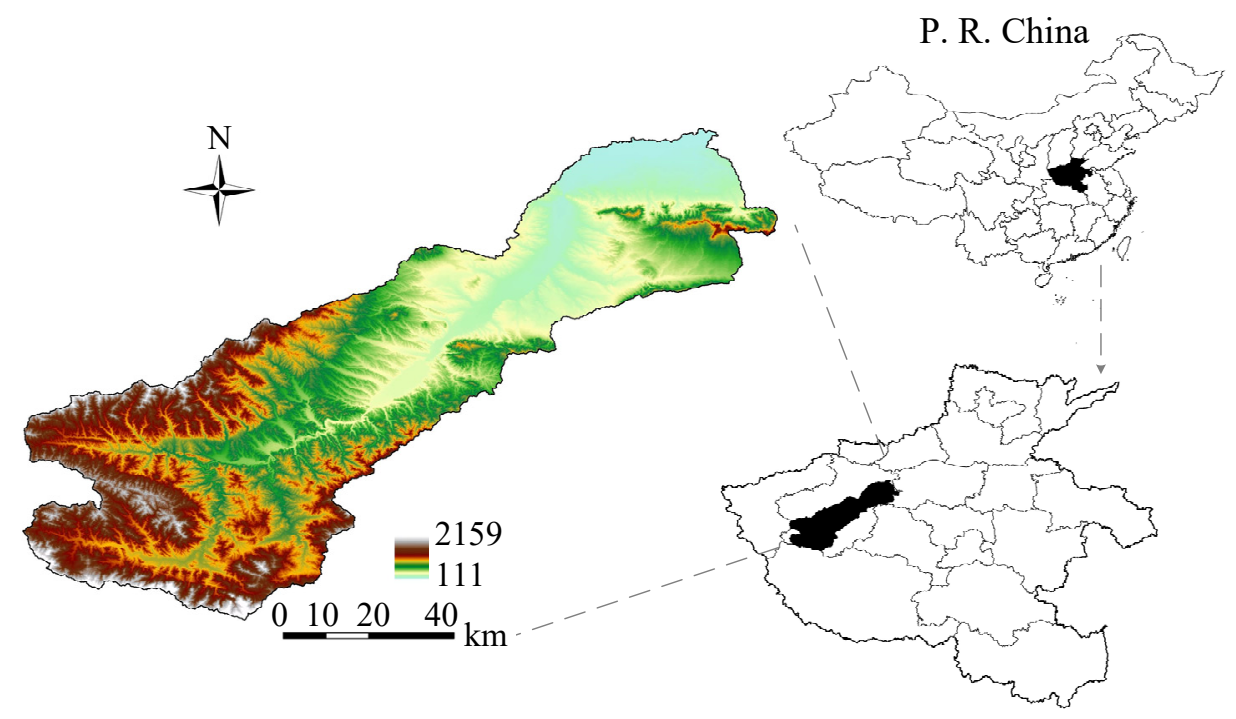

Henan Province

Figure 1. The location of the Yi River basin.

The elevation ranges from $111 \mathrm{~m}$ to $2159 \mathrm{~m}$. The natural landforms are mountains, hills and valley plains, with proportions of $50 \%, 40 \%$ and $10 \%$, respectively. The main landcover types are forests, cropland, grassland, and impervious surfaces. The basin is located on the border of China's warm temperate zone and north subtropical region; hence, there is an obvious transition from southwest to northeast, such as the precipitation progressively declining by an average of 700 900 mm. Forests are mainly concentrated in the southwest, with a total area of $3119.86 \mathrm{~km}^{2}$ in 2020 , which accounted for $53 \%$ of the whole basin. Deciduous, broad-leaved forests are dominant in the Yi River basin. The proportion of this type of forest is nearly $99 \%$ of the whole forest area. The other types of forests are evergreen needle-leaved forest, deciduous needle-leaved forest, and mixed forest. The natural protection is good in this basin. However, with the acceleration of urbanization, the natural environment has been disturbed by human activity. Driven by local policies, a series of ecological restoration plans have been implemented.

\subsection{Data Resources}

The DEM data (with 30 m precision) of the CPEZ were obtained from the National Science and Technology Infrastructure Center-National Earth System Science Data Sharing Infrastructure-Data Center of Lower Yellow River Regions.

Landscape data were collected from the data center of Tsinghua University, which contains the Global Land Cover with Fine Classification System at $30 \mathrm{~m}$ in 2015 and 2020 (GLC_FCS30-2015, GLC_FCS30-2020) [24]. Within this, overall GLC_FCS30-2015 and GLC_FCS30-2020 accuracies of $82.5 \%$ and $88.9 \%$, respectively, were achieved.

\subsection{Classification of Landform Types}

Landform can directly or indirectly decide the distribution and utilization of different land use types. Here, we used the spatial analytic tool in ArcMap 10.3 (Esri Inc., Redlands, CA, USA) to classify landform types by elevation. The areas with elevation lower than $200 \mathrm{~m}$ were valley plains, between $200 \mathrm{~m}$ and $500 \mathrm{~m}$ were hills, between $500 \mathrm{~m}$ and $1000 \mathrm{~m}$ were low mountains, and above $1000 \mathrm{~m}$ were middle mountains (Figure 2). In this study, we mainly analyzed the connectivity characteristics of forest landscapes in hills and low mountains. During FLR, rainfed cropland patches are most likely to be returned to forest patches [14]. Hence, we also focused on the connectivity characteristics of rainfed cropland in hills and mountains, to analyze the importance of rainfed cropland patches on FLR. 


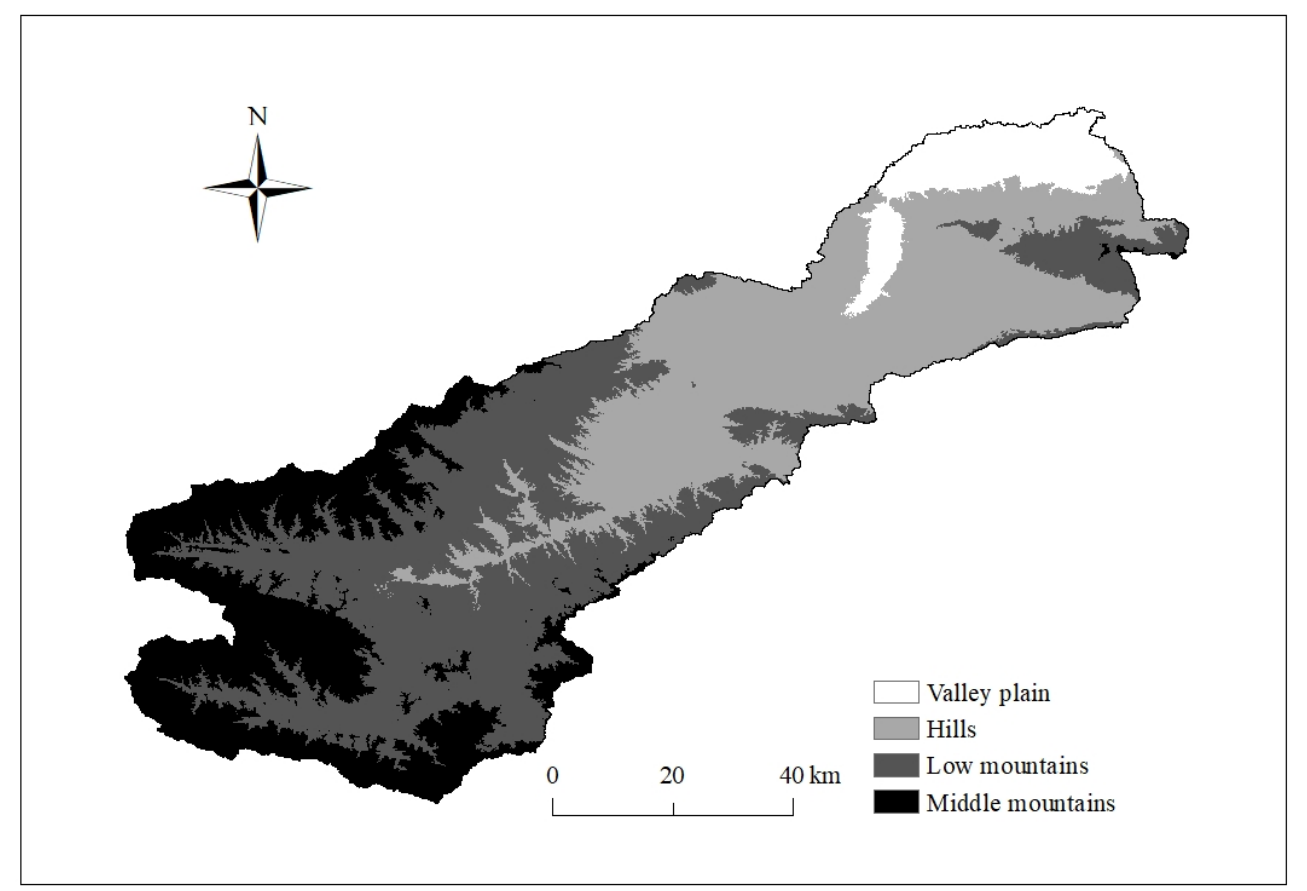

Figure 2. Landform classification of the Yi River basin.

\subsection{Analysis of the FLC}

We select forest patches with areas greater than 6 ha. Then, we used Conefor 2.6 (Duke University, Durham, NC, USA) to analyze landscape connectivity. We selected two binary indices, NC and IIC, to represent the FLC in the Yi River basin. Based on the result of IIC, we calculated dIIC to show the importance of patches that were reforested from rainfed cropland for the improvement of FLC.

NC represents the number of components. A component is a group of interconnected patches, and different components are isolated from each other. As a landscape becomes more connected, it will present fewer components [25]. When NC is equal to 1, it means that all the patches in the landscape are connected, and are subordinated to the same component. Moreover, the NC value does not change any more when the distance threshold increases.

IIC is the best binary index for analyzing landscape connectivity in this software $[26,27]$. It ranges from 0 to 1 and increases with improved connectivity. The increasing distance threshold provides larger searching ranges, and it is much easier for two random patches to connect with each other. The calculation formula is:

$$
\mathrm{IIC}=\frac{\sum_{i=1}^{n} \sum_{j=1}^{n} \frac{a_{i} \cdot a_{j}}{1+n l_{i j}}}{A_{L}^{2}}
$$

Here, $n$ is the total number of patches in the landscape, $a_{i}$ and $a_{j}$ are the areas of patches $i$ and $j, n l_{i j}$ is the number of links in the shortest path (topological distance) between patches $i$ and $j$, and $A_{L}$ is the maximum landscape area (which includes forest landscape patches and non-forest landscape patches).

The dIIC value can indicate the importance of a patch and helps to filter out the priority patches. Before the calculation, we screened out the rainfed cropland patches in 2015 and forest patches in 2020, and used the intersection tool in ArcGIS 10.3 (Esri Inc., Redlands, CA, USA) to obtain the reforested patches during this period. Patches with areas smaller than 6 ha were deleted. The calculation formula is:

$$
\operatorname{dIIC}(\%)=100 \cdot \frac{\mathrm{IIC}_{\text {reforested }}-\text { IIC }}{\text { IIC }}
$$


Here, $\mathrm{IIC}_{\text {reforested }}$ is the IIC value of newly formed forest landscape from the reforested rainfed cropland. Using natural break classification to classify the dIIC values into five levels depends on the importance degree, which were very low, low, medium, high, and very high in this analysis.

\subsection{Selection of the Distance Thresholds}

Calculations of landscape connectivity indices require the distance thresholds of landscape patches. When the distances between patches are greater than the thresholds, the patches are not considered to be connected; in contrast, when thresholds are greater than the distances, the patches are connected. Patch connectivity is related to the characteristics of organisms' migration and diffusion processes [16,28-30]. Based on the records of historical documents and statistical yearbooks, we have roughly investigated wildlife activity ranges in the Yi River basin. We set ten distance thresholds, $0.1 \mathrm{~km}, 0.5 \mathrm{~km}, 1 \mathrm{~km}, 2.5 \mathrm{~km}, 5 \mathrm{~km}$, $7.5 \mathrm{~km}, 10 \mathrm{~km}, 15 \mathrm{~km}, 17.5 \mathrm{~km}$ and $20 \mathrm{~km}$, when calculating the FLC.

\section{Results}

\subsection{Land Cover Change between 2015 and 2020}

It is obvious that the area of forest landscape has expanded from 2015 to 2020 (Figure 3). In 2015 , the area of forest landscape was $2639.07 \mathrm{~km}^{2}$, occupying $45.5 \%$ of the total study area. In 2020, the area of forest landscape had expanded to $3119.86 \mathrm{~km}^{2}$, occupying $53.8 \%$ of the total area. During this five-year period, $142.64 \mathrm{~km}^{2}$ of rainfed cropland has been transferred into forests, while a larger area of rainfed cropland has been transformed into irrigated cropland. These changes followed the local policies. The RFFP promoted rainfed cropland to be turned into forests, and the vigorous development of water-saving agriculture has turned rainfed cropland into irrigated cropland. It is worth noting that $334.31 \mathrm{~km}^{2}$ of grassland has been transformed into forests; the converted area is more than twice that of rainfed cropland (Table 1). Grassland here was mainly an area for tending young and newly afforested forests. Hence, the five-year changes clearly show the results of FLR in the Yi River basin.

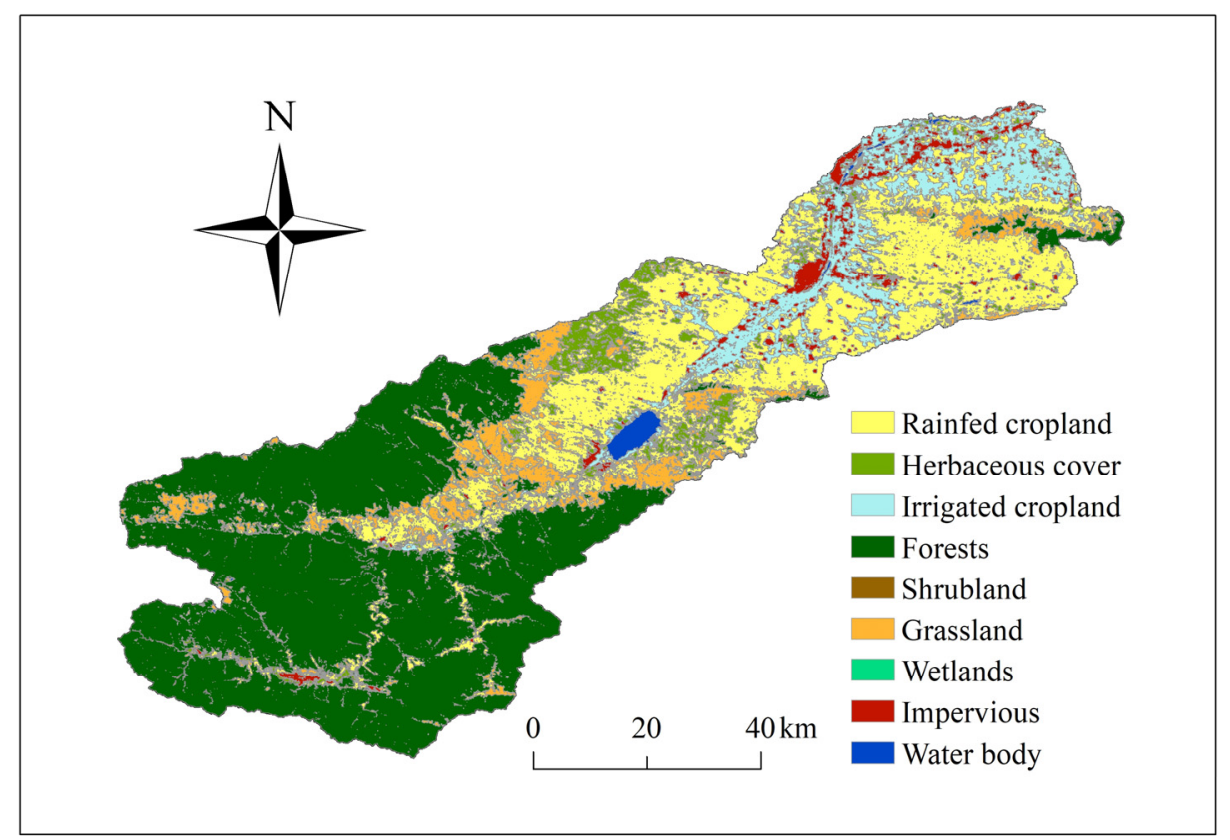

Figure 3. Cont. 


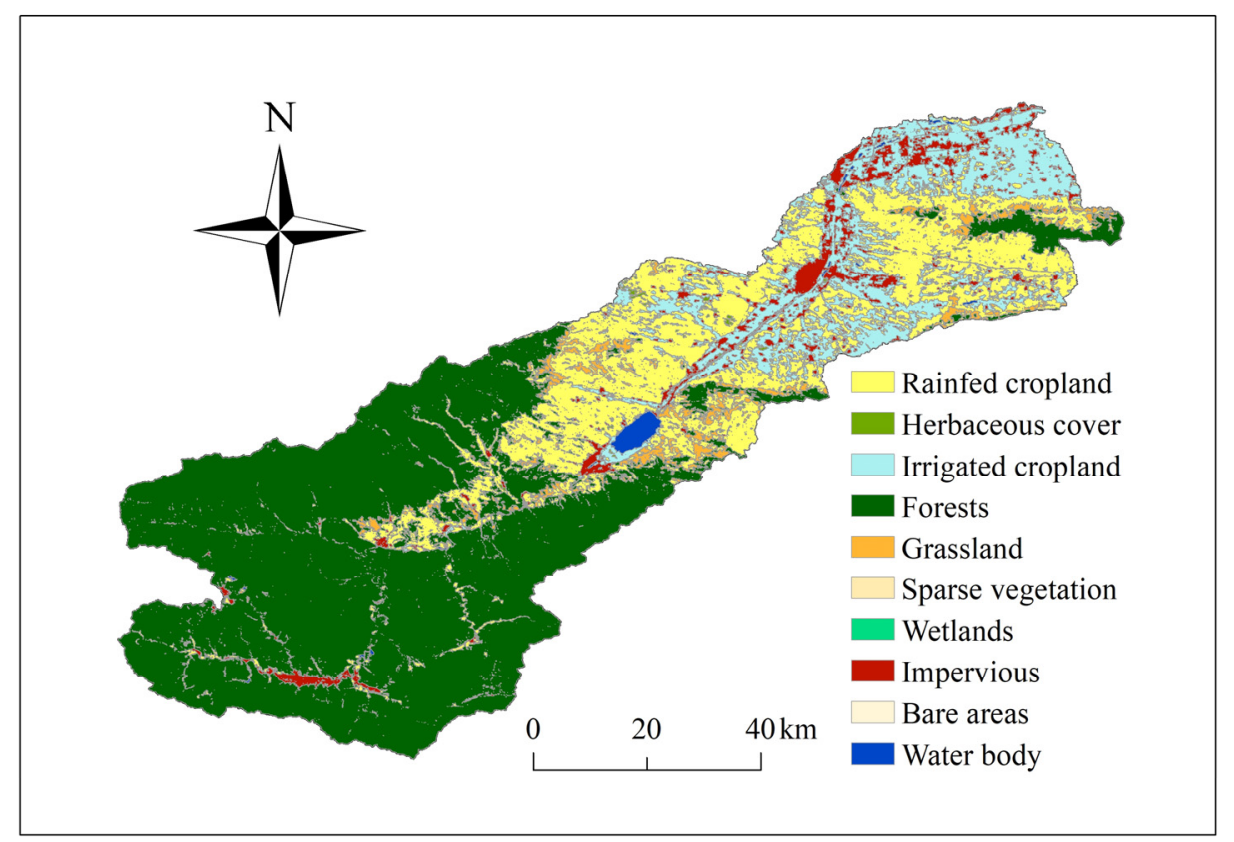

(b)

Figure 3. (a) Land cover of the Yi River basin in 2015; (b) Land cover of the Yi River basin in 2020.

Table 1. Land cover area $\left(\mathrm{km}^{2}\right)$ transfer matrix in the Yi River basin.

\begin{tabular}{ccccc}
\hline 2015 & Rainfed Cropland & Irrigated Cropland & Forests & Grassland \\
\hline Rainfed cropland & - & 266.26 & 142.64 & 69.18 \\
Irrigated cropland & 101.72 & - & 6.19 & 3.08 \\
Forests & 10.31 & 1.23 & - & 5.03 \\
Grassland & 60.06 & 1.29 & 334.31 & - \\
\hline
\end{tabular}

\subsection{Variation of FLC between 2015 and 2020}

Results show that NC values both in hills and low mountains were generally decreased as the distance thresholds increased, and then declined to 1 . IIC values increased as the distance threshold increased. Within the same distance thresholds, IIC values in hills decreased from 2015 to 2020, whereas those in low mountains rose in this period (Tables 2 and 3). During the research period, the FLC in low mountain areas exhibited a rising trend, whereas in hills, it exhibited a downward trend.

\subsection{Selection of an Appropriate Distance Threshold for Landscape Connectivity}

Results of the FLC indices show, that in hilly areas, when the distance threshold was greater than $2500 \mathrm{~m}$, the number of components was stably reduced to 1 , and the numbers of patches in the largest components increased to 761 and 740, respectively (Table 2), which meant that the forest landscape had achieved full connection. Therefore, $2500 \mathrm{~m}$ was the greatest distance threshold forests in the hills; an appropriate distance threshold is less than $2500 \mathrm{~m}$. In the low mountains, when the distance threshold was greater than $1000 \mathrm{~m}$, the number of components was stably reduced to 1 , and the numbers of patches in the largest components increased to 396 and 367, respectively. Hence, $1000 \mathrm{~m}$ is the greatest distance threshold for forests in the low mountains.

Apart from the diffusion distances of species, the enforceability of landscape connectivity and the objective demands for different levels should also be considered when selecting the appropriate distance threshold [22]. The trends of NC and the number of patches in the largest component under different distance thresholds intersects; this inter- 
section shows the appropriate distance threshold. The results show that the appropriate distance threshold of hills is $500 \mathrm{~m}$ (Figure 4), and the appropriate distance threshold of low mountains is $100 \mathrm{~m}$ (Figure 5). A lower distance threshold can better reflect the subtle relationships among landscape patches.

Table 2. FLC indices of hills under different distance thresholds.

\begin{tabular}{|c|c|c|c|c|c|c|c|c|}
\hline \multirow{3}{*}{$\begin{array}{c}\text { Distance } \\
\text { Threshold (m) }\end{array}$} & \multicolumn{4}{|c|}{2015} & \multicolumn{4}{|c|}{2020} \\
\hline & \multirow[b]{2}{*}{ NC } & \multirow[b]{2}{*}{ IIC } & \multicolumn{2}{|c|}{ The Largest Component } & \multirow[b]{2}{*}{ NC } & \multirow[b]{2}{*}{ IIC } & \multicolumn{2}{|c|}{ The Largest Component } \\
\hline & & & $\begin{array}{l}\text { Patch Amount } \\
\text { (Proportion/\%) }\end{array}$ & $\begin{array}{l}\text { Patch Area }\left(\mathrm{km}^{2}\right) \\
\text { (Proportion/\%) }\end{array}$ & & & $\begin{array}{l}\text { Patch Amount } \\
\text { (Proportion/\%) }\end{array}$ & $\begin{array}{c}\text { Patch Area }\left(\mathrm{km}^{2}\right) \\
\text { (Proportion/\%) }\end{array}$ \\
\hline 100 & 490 & 0.0032 & $26(3.4)$ & 30.06 (10.9) & 432 & 0.0028 & $22(3.0)$ & $21.88(8.7)$ \\
\hline 500 & 129 & 0.0046 & $111(15.0)$ & $62.25(22.5)$ & 143 & 0.0046 & $248(33.5)$ & $99.08(39.5)$ \\
\hline 1000 & 34 & 0.0069 & $394(51.8)$ & $140.55(50.8)$ & 45 & 0.0059 & $380(51.4)$ & $129.52(51.6)$ \\
\hline 2500 & 4 & 0.0098 & 756 (99.3) & $274.81(99.2)$ & 2 & 0.0088 & 737 (99.6) & 250.15 (99.6) \\
\hline 5000 & 1 & 0.0119 & $761(100)$ & $276.92(100)$ & 1 & 0.0108 & $740(100)$ & $251.08(100)$ \\
\hline
\end{tabular}

Table 3. FLC indices of low mountains under different distance thresholds.

\begin{tabular}{|c|c|c|c|c|c|c|c|c|}
\hline \multirow{3}{*}{$\begin{array}{c}\text { Distance } \\
\text { Threshold (m) }\end{array}$} & \multicolumn{4}{|c|}{2015} & \multicolumn{4}{|c|}{2020} \\
\hline & \multirow[b]{2}{*}{$\mathrm{NC}$} & \multirow[b]{2}{*}{ IIC } & \multicolumn{2}{|c|}{ The Largest Component } & \multirow[b]{2}{*}{$\mathrm{NC}$} & \multirow[b]{2}{*}{ IIC } & \multicolumn{2}{|c|}{ The Largest Component } \\
\hline & & & $\begin{array}{l}\text { Patch Amount } \\
\text { (Proportion/\%) }\end{array}$ & $\begin{array}{c}\text { Patch Area }\left(\mathrm{km}^{2}\right) \\
\text { (Proportion/\%) }\end{array}$ & & & $\begin{array}{l}\text { Patch Amount } \\
\text { (Proportion/\%) }\end{array}$ & $\begin{array}{c}\text { Patch Area }\left(\mathrm{km}^{2}\right) \\
\text { (Proportion/\%) }\end{array}$ \\
\hline 100 & 170 & 0.076 & $83(21.0)$ & $1198.42(77.6)$ & 117 & 0.100 & $189(51.5)$ & $1399.77(87.7)$ \\
\hline 500 & 36 & 0.084 & $267(67.4)$ & $1402.65(90.8)$ & 28 & 0.103 & $266(72.5)$ & $1447.46(90.7)$ \\
\hline 1000 & 10 & 0.085 & $300(75.8)$ & $1411.08(91.4)$ & 12 & 0.104 & $287(78.2)$ & $1450.76(90.9)$ \\
\hline 2500 & 5 & 0.088 & $302(76.3)$ & $1411.31(91.4)$ & 6 & 0.105 & $289(78.8)$ & $1450.93(91.0)$ \\
\hline 5000 & 4 & 0.093 & $328(82.8)$ & $1443.62(93.5)$ & 4 & 0.107 & $315(85.8)$ & $1485.43(93.1)$ \\
\hline 15,000 & 2 & 0.100 & $337(85.1)$ & $1445.67(93.6)$ & 2 & 0.111 & $319(86.9)$ & $1493.01(93.6)$ \\
\hline 17,500 & 1 & 0.103 & $396(100)$ & $1544.37(100)$ & 1 & 0.115 & $367(100)$ & $1595.31(100)$ \\
\hline
\end{tabular}

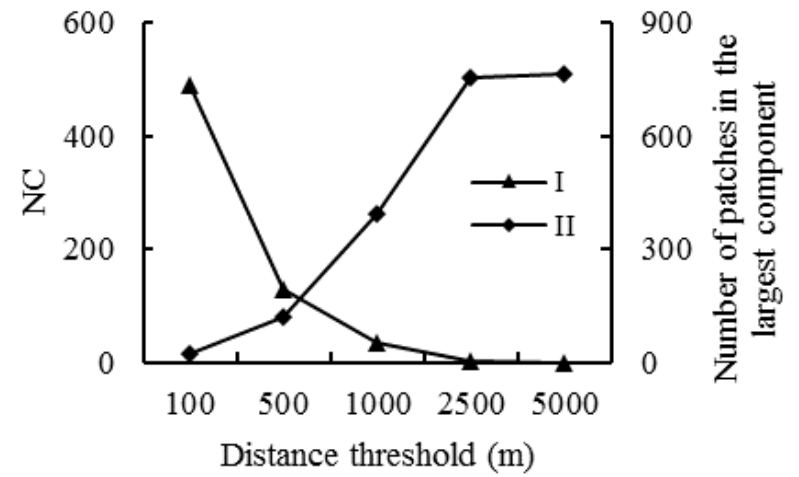

(a)

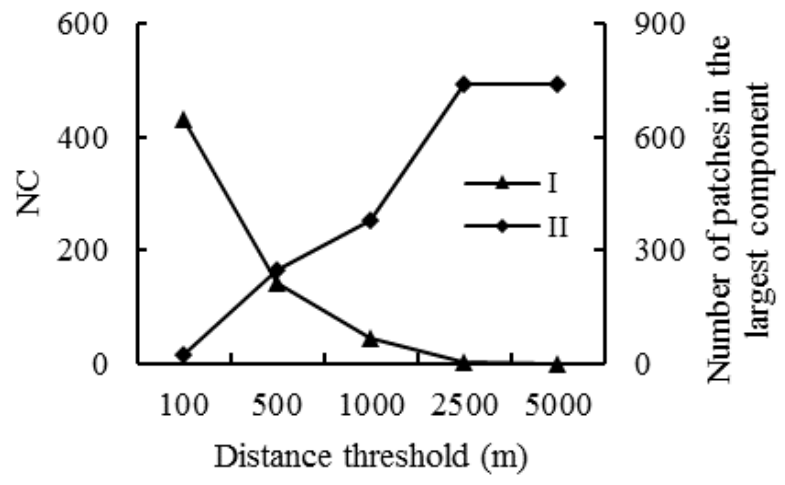

(b)

Figure 4. NC (I) and the number of patches in the largest component (II) of forest in hills under different distance thresholds in 2015 (a) and 2020 (b). 


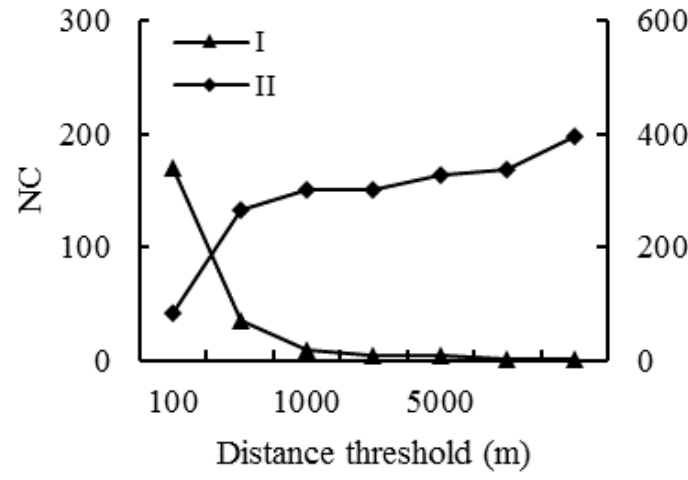

(a)

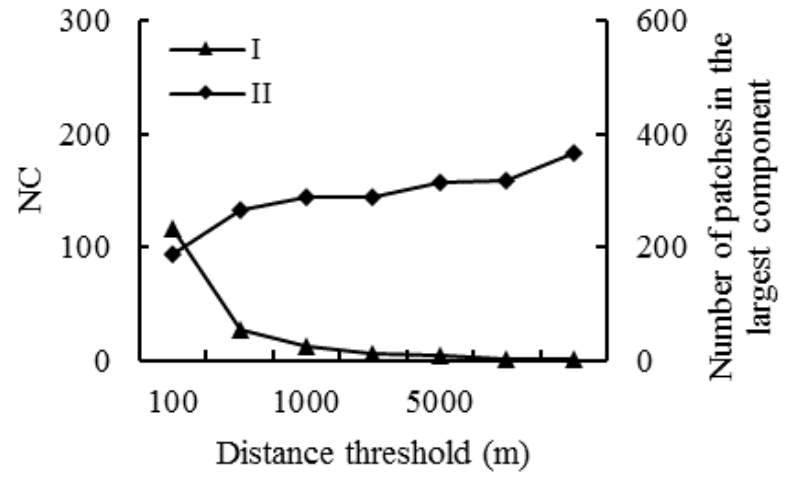

(b)

Figure 5. NC (I) and the number of patches in the largest component (II) of forest in low mountains under different distance thresholds in 2015 (a) and 2020 (b).

\subsection{Analysis of dIIC of Rainfed Cropland Patches}

With the increasing distance thresholds, the overall trend in the maximum values of dIIC ( IIIC $\left._{\max }\right)$ for rainfed cropland patches in hill was downward, and when the distance threshold was larger than $7500 \mathrm{~m}$, the variation range was narrow. In low mountains, there was a floating change in $\mathrm{dIIC}_{\max }$ under different distance thresholds (Table 4). However, when the distance threshold was larger than $5000 \mathrm{~m}$, the variation range became narrow.

Table 4. Values of $\mathrm{dIIC}_{\max }$ for rainfed cropland patches under different distance thresholds.

\begin{tabular}{ccccccccccc}
\hline & $\mathbf{1 0 0}$ & $\mathbf{5 0 0}$ & $\mathbf{1 0 0 0}$ & $\mathbf{2 5 0 0}$ & $\mathbf{5 0 0 0}$ & $\mathbf{7 5 0 0}$ & $\mathbf{1 0 , 0 0 0}$ & $\mathbf{1 5 , 0 0 0}$ & $\mathbf{1 7 , 5 0 0}$ & $\mathbf{2 0 , 0 0 0}$ \\
\hline Hills & 25.96 & 23.70 & 18.75 & 15.23 & 12.39 & 10.17 & 10.21 & 10.47 & 10.21 & 9.93 \\
Low Mountains & 13.33 & 28.31 & 28.84 & 12.57 & 8.07 & 6.24 & 5.65 & 5.48 & 8.37 & 8.61 \\
\hline
\end{tabular}

According to the calculation results above, we chose $500 \mathrm{~m}$ as the distance threshold for hills, and $100 \mathrm{~m}$ as the distance threshold for low mountains. The levels of contributions for each rainfed cropland patch are visualized in Figure 6.

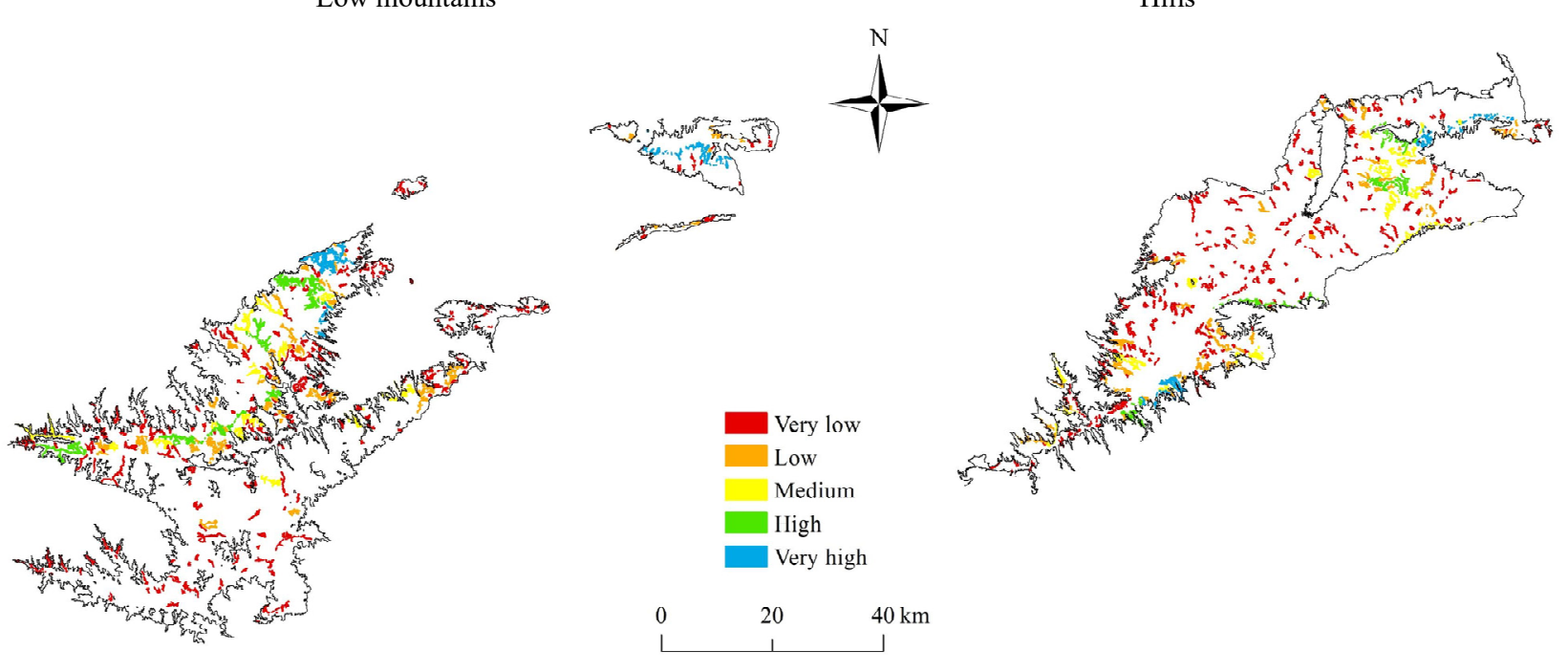

Figure 6. Contribution of reforested patches to the improvement of FLC. 
In hills, eight reforested patches made "very high" and "high" contributions to improving the FLC, which occupied $15.6 \%$ of the total reforested area. Fifteen reforested patches in low mountains made "very high" and "high" contributions to improving the FLC, and the proportion was $25.5 \%$ (Table 5). By visualizing the importance of each patch that had been reforested from rainfed cropland, it can clearly be seen that their contributions to improve the FLC are different. Some patches with small areas could still contribute considerably.

Table 5. Information of reforested patches in hills and low mountains at different levels.

\begin{tabular}{ccccccc}
\hline & \multicolumn{3}{c}{ Patches in Hills } & \multicolumn{2}{c}{ Patches in Low Mountains } \\
\cline { 2 - 7 } & Amount & Area $\left.\mathbf{( k m}^{\mathbf{2}}\right)$ & Proportion of Total Area & Amount & Area $\mathbf{( k m}^{2}$ ) & Proportion of Total Area \\
\hline Very low & 214 & 24.29 & $43.8 \%$ & 212 & 27.97 & $38.8 \%$ \\
Low & 61 & 13.28 & $23.9 \%$ & 51 & 15.06 & $20.9 \%$ \\
Medium & 25 & 9.20 & $16.6 \%$ & 17 & 10.75 & $14.9 \%$ \\
High & 6 & 4.46 & $8.0 \%$ & 9 & 10.57 & $14.7 \%$ \\
Very high & 2 & 4.22 & $7.6 \%$ & 6 & 7.76 & $10.8 \%$ \\
\hline
\end{tabular}

\section{Discussion}

The Yi River basin is located in a major area of national forest reserves in Henan province. This region is an important ecological shelter. According to the local 13th Five-Year Plan, it is known that the most important task was to fully stop commercial felling during 2015 and 2020, and then actively implementing a new round of the RFFP scheme. Through the analysis of land cover changes between 2015 and 2020, it is clear that some rainfed cropland has been converted into forest. There are also certain areas of grassland which have been converted to forest during this period. According to field investigations, these grasslands were planned to tend young, newly afforested forests. It is obvious that under the RFFP, areas of artificial forest are continuously increasing. For the first few years, the species composition of these artificial forests was not comparable with natural forests, but the ecological value of FLR in the study area will evolve over time. Hence, long-term observations should be part of future work.

Landscape connectivity is codetermined by the structural characteristics of landscapes and the behavioral characteristics of organisms. Hence, the degree of connection of the same landscape is not necessarily the same from different perspectives. Species with high diffusivity can easily migrate from one patch to another, whereas species with low diffusivity need some stepping-stones between patches during their migration. Especially in this study, forest areas were small and scattered in hills. Reforested patches with greater importance to the FLC are vital to conserve biodiversity. In many studies, the distance thresholds are relatively small; most of them are less than $500 \mathrm{~m}$ [14,22]. In this study, the $\mathrm{dIIC}_{\max }$ value of reforested patches in hills was the greatest when the distance threshold was less than $500 \mathrm{~m}$. This distance slightly overlaps with the main diffusion distances of small rodents, reptiles and amphibians. These animals are low on the food chain; therefore, ensuring their species connectivity can benefit the maintenance of ecosystem stability.

In other words, to evaluate the importance of potential reforested patches on improving FLC before FLR is of great significance. Analysis of the landscape connectivity index based on spatial graph theory can provide applicable, practical methods, especially for species with different diffusivities in FLR. Through the analysis in our study, it is obvious that the importance of patches reforested from rainfed cropland is significant. Considering the most important patches before FLR proceeds can effectively improve the FLC, thus promoting the effective conservation of biodiversity.

However, there are still some shortcomings in this research. The calculation of landscape connectivity and division of patch components depends on the geometric distance between two random patches; we did not take landscape heterogeneity and differences in land cover resistance into account. In addition, the biological characteristics of regional species and their dispersal capacity also need to be further considered and analyzed. Furthermore, discovering how to analyze FLC for certain species in larger areas based on the 
landscape connectivity method would be important to develop understandings of forest ecosystem functions.

\section{Conclusions}

This study provides an applicable and practical way to select important patches during FLR through the analysis of FLC. Combined with simply describing the status of landscape patterns by landscape indices, this method could clearly identify the contribution degree of each afforested patch of rainfed cropland for improvements in FLC. Accordingly, this could be utilized to select important patches and decide the restoring order at the beginning of FLR. In theory, this method could be applied to other territorial contexts. This study has referential significance on the conservation of regional biodiversity and improvements of forest ecosystem functions.

Author Contributions: Conceptualization, Z.B. and L.L.; methodology, Z.B.; software, L.L.; validation, Z.B., L.L. and S.D.; formal analysis, Z.B. and L.L.; investigation, Z.B. and L.L.; resources, S.D.; data curation, L.L.; writing-original draft preparation, Z.B. and L.L.; writing-review and editing, L.L. and S.D.; visualization, Z.B. and L.L.; supervision, S.D.; project administration, S.D.; funding acquisition, S.D. All authors have read and agreed to the published version of the manuscript.

Funding: This research was funded by the National Natural Science Foundation of China (41771202).

Institutional Review Board Statement: Not applicable.

Informed Consent Statement: Not applicable.

Conflicts of Interest: The authors declare no conflict of interest.

\section{References}

1. Taylor, P.D.; Fahrig, L.; Henein, K.; Merriam, G. Connectivity Is a Vital Element of Landscape Structure. Oikos 1993, 68, 571. [CrossRef]

2. Wu, C.; Zhou, Z.; Wang, P.; Xiao, W.; Teng, M. The concept and measurement of landscape connectivity and its applications. Acta Ecol. Sin. 2010, 30, 1903-1910.

3. Dunning, J.B.; Danielson, B.J.; Pulliam, H.R. Ecological Processes That Affect Populations in Complex Landscapes. Oikos 1992, 65, 169. [CrossRef]

4. Chen, C.; Jia, Z.; Wu, S.; Tong, X.; Zhou, W.; Chen, R.; Zhang, C. A bibliometric review of Chinese studies on the application of landscape connectivity. Acta Ecol. Sin. 2017, 37, 3243-3255. [CrossRef]

5. Chen, L.; Fu, B. The ecological significance and application of landscape connectivity. Chin. J. Ecol. 1996, 15, 37-42. [CrossRef]

6. Yu, K. Landscape ecological security patterns in biological conservation. Acta Ecol. Sin. 1999, 9, 8-15. [CrossRef]

7. Kong, F.; Yin, H. Developing green space ecological networks in Jinan City. Acta Ecol. Sin. 2008, 28, 1711-1719.

8. Chang, H.; Li, F.; Li, Z.; Wang, R.; Wang, Y. Urban landscape pattern design from the viewpoint of networks: A case study of Changzhou city in Southeast China. Ecol. Complex. 2011, 8, 51-59. [CrossRef]

9. Jiao, S.; Li, Z.; Gao, Q.; Zhou, K.; Wei, C.; He, S. The application of landscape connectivity theory in urban ecology suitability assessment and optimization. Geogr. Res. 2013, 32, 720-730. [CrossRef]

10. Ren, Y.; Deng, L.; Zuo, S.; Luo, Y.; Shao, G.; Wei, X.; Hua, L.; Yang, Y. Geographical modeling of spatial interaction between human activity and forest connectivity in an urban landscape of southeast China. Landsc. Ecol. 2014, 29, 1741-1758. [CrossRef]

11. Chen, L.; Liu, X.; Fu, B. Evaluation on giant panda habitat fragmentation in Wolong nature reserve. Acta Ecol. Sin. 1999, 19, $291-297$.

12. Liang, G. Study on the Impact of Land Use Change on Landscape Connectivity: A Case Study of Gongyi City; Physical Geography and Ecological Security: Lanzhou, China, 2012.

13. Liang, G.; Xu, L.; Ding, S. Impacts of roads on woodland landscape connectivity: A case study of Gongyi City, Henan Province. Acta Ecol. Sin. 2014, 34, 4775-4784. [CrossRef]

14. Chen, J.; Liang, G.; Ding, S. Landscape connectivity analysis for the forest landscape restoration: A case study of Gongyi City. Acta Ecol. Sin. 2012, 32, 3773-3781. [CrossRef]

15. Crist, M.R.; Wilmer, B.; Aplet, G.H. Assessing the value of roadless areas in a conservation reserve strategy: Biodiversity and landscape connectivity in the northern Rockies. J. Appl. Ecol. 2005, 42, 181-191. [CrossRef]

16. Watts, K.; Handley, P. Developing a functional connectivity indicator to detect change in fragmented landscapes. Ecol. Indic. 2010, 10, 552-557. [CrossRef]

17. Mansourian, S. From landscape ecology to forest landscape restoration. Landsc. Ecol. 2021, 36, 2443-2452. [CrossRef]

18. César, R.G.; Belei, L.; Badari, C.G.; Viani, R.A.G.; Chazdon, R.L.; Gutierrez, V.; Brancalion, P.H.S.; Morsello, C. Forest and Landscape Restoration: A Review Emphasizing Principles, Concepts, and Practices. Land 2020, 10, 28. [CrossRef] 
19. Newton, A.C.; Echeverría, C.; Malizia, L.R.; Premoli, A.C.; Del Castillo, R.F.; Geneletti, D.; González-Espinosa, M.; Benayas, J.M.R.; Smith-Ramírez, C.; Williams-Linera, G. Forest Landscape Restoration in the Drylands of Latin America. Ecol. Soc. 2012, 17, 21. [CrossRef]

20. Stanturf, J.A.; Kleine, M.; Mansourian, S.; Parrotta, J.; Madsen, P.; Kant, P.; Burns, J.; Bolte, A. Implementing forest landscape restoration under the Bonn Challenge: A systematic approach. Ann. For. Sci. 2019, 76, 50. [CrossRef]

21. García-Feced, C.; Saura, S.; Elena-Rosselló, R. Improving landscape connectivity in forest districts: A two-stage process for prioritizing agricultural patches for reforestation. For. Ecol. Manag. 2011, 261, 154-161. [CrossRef]

22. Liu, C.; Zhou, B.; He, X.; Chen, W. Selection of distance thresholds of urban forest landscape connectivity in Shenyang City. Chin. J. Appl. Ecol. 2010, 21, 2508-2516. [CrossRef]

23. Hu, W.; Wang, S.; Li, D. Biological conservation security patterns plan in Beijing based on the focal species approach. Acta Ecol. Sin. 2010, 30, 4266-4276.

24. Global Land Cover with Fine Classification System. Available online: http:/ / data.ess.tsinghua.edu.cn/ (accessed on 19 August 2021).

25. Conefor Sensinode 2.2 User's Manual. Available online: http:/ / conefor.org/files/usuarios/CS22manual.pdf (accessed on 4 June 2021).

26. Pascual-Hortal, L.; Saura, S. Comparison and development of new graph-based landscape connectivity indices: Towards the priorization of habitat patches and corridors for conservation. Landsc. Ecol. 2006, 21, 959-967. [CrossRef]

27. Saura, S.; Pascual-Hortal, L. A new habitat availability index to integrate connectivity in landscape conservation planning: Comparison with existing indices and application to a case study. Landsc. Urban. Plan. 2007, 83, 91-103. [CrossRef]

28. Gonzalez, J.R.; del Barrio, G.; Duguy, B. Assessing functional landscape connectivity for disturbance propagation on regional scales-A cost-surface model approach applied to surface fire spread. Ecol. Model. 2008, 211, 121-141. [CrossRef]

29. MorzilloJoseph, A.T.; Ferrari, J.R.; Liu, J. An integration of habitat evaluation, individual based modeling, and graph theory for a potential black bear population recovery in southeastern Texas, USA. Landsc. Ecol. 2011, 26, 69-81. [CrossRef]

30. Saura, S.; Estreguil, C.; Mouton, C.; Rodríguez-Freire, M. Network analysis to assess landscape connectivity trends: Application to European forests (1990-2000). Ecol. Indic. 2011, 11, 407-416. [CrossRef] 